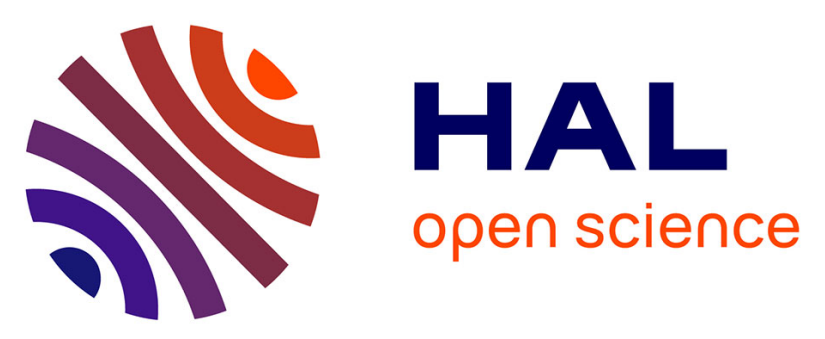

\title{
Towards a RAS mutation status in a single day for patients with advanced colorectal cancers. Authors' Reply
}

Astrid Lièvre, Jean-Louis Merlin, Jean-Christophe Sabourin, Pascal Artru, Pierre Laurent-Puig, Michel Ducreux

\section{To cite this version:}

Astrid Lièvre, Jean-Louis Merlin, Jean-Christophe Sabourin, Pascal Artru, Pierre Laurent-Puig, et al.. Towards a RAS mutation status in a single day for patients with advanced colorectal cancers. Authors' Reply. Digestive and Liver Disease, 2018, 50 (9), pp.974-975. 10.1016/j.dld.2018.06.014 . hal-01902490

\section{HAL Id: hal-01902490 \\ https://hal-univ-rennes1.archives-ouvertes.fr/hal-01902490}

Submitted on 7 Nov 2018

HAL is a multi-disciplinary open access archive for the deposit and dissemination of scientific research documents, whether they are published or not. The documents may come from teaching and research institutions in France or abroad, or from public or private research centers.
L'archive ouverte pluridisciplinaire HAL, est destinée au dépôt et à la diffusion de documents scientifiques de niveau recherche, publiés ou non, émanant des établissements d'enseignement et de recherche français ou étrangers, des laboratoires publics ou privés. 


\section{Towards a RAS mutation status in a single day for patients with advanced colorectal cancers. Authors' reply}

Astrid Lièvre, ${ }^{\mathrm{a}, \mathrm{b}, \mathrm{c}, *}$, M.D., Ph.D., Jean-Louis Merlin ${ }^{\mathrm{d}, \mathrm{e}, \mathrm{f}}$, Pharm.D., Ph.D., Jean-Christophe Sabourin $^{\text {g,h }}$, M.D., Pascal Artru', M.D., Pierre Laurent-Puig ${ }^{\mathrm{j}, \mathrm{k}}$, M.D., Michel Ducreux', M.D.

a Department of Gastroenterology, CHU Pontchaillou, 2 Rue Henri le Guilloux, 35000 Rennes

b University of Rennes 1, 2 Avenue du Professeur Léon Bernard, 35000 Rennes, France c INSERM U1242, Oncogenesis, Stress \& Signaling, rue de la Bataille Flandres Dunkerque, 35000 Rennes, France

d University of Lorraine, 34 Cours Léopold, 54000 Nancy, France

e CNRS UMR7039 CRAN, Boulevard des Aiguillettes, 54506 Vandoeuvre-lès-Nancy,

France

${ }^{\mathrm{f}}$ Biopathology Department, Cancer Institute of Lorraine, 6 Avenue de Bourgogne, 54519 Vandoeuvre-lès-Nancy, France

g Pathology Department, CHU Charles Nicolle, 1 Rue de Germont, 76000 Rouen, France

h Inserm 1079, University of Normandy, 22 Boulevard Gambetta, 76183 Rouen, France

i Department of digestive oncology, Jean Mermoz Hospital, 55 Avenue Jean Mermoz, 69008 Lyon, France

j UMRS-1174 Personnalized Medicine, Pharmacogenomic, Therapeutic Optimization;

Paris Descartes University, 12 Rue de l'Ecole de Médecine, 75006 Paris, France

k Department of Biology, Georges Pompidou European Hospital, 20 Rue Leblanc, 75015

Paris, France

${ }^{1}$ Department of Oncology, Gustave Roussy, 114 Rue Edouard Vaillant, 94800 Villejuif,

Paris-Saclay University, France

* Corresponding author: Astrid Lièvre, Service Maladies de l'appareil digestif, CHU Pontchaillou, 2 Rue Henri le Guilloux, 35000 Rennes. Tel.: +33 (0)299289972; Fax: +33 (0)299284189; e-mail: astrid.lievre@chu-rennes.fr

Keywords: colorectal cancer; RAS mutation; turnaround time; quality

Dear Editor,

We thank Dr Barel et al. for their letter concerning our article [1]. In this letter, the authors reported their experience of 1264 RAS tests performed between 2015 and 2017 in a French area of Brittany using a massively parallel sequencing method. Even if the mean duration between receipt of tumour samples by the Molecular Genetics platform and the transmission of the RAS test report was shorter than that we previously reported (11.03 days versus 19.5 in our study), it exceeds anyway the recommended duration between test request and results feedback [2-4]. Indeed, as mentioned by the authors, this delay does not take into account the time between the request of RAS test by physicians and the receipt of tumour samples by the molecular genetics platform, which may take a long time, especially when tumour samples have been archived in other regional institutions than the Hospital where the molecular genetics platform is located. Moreover, it is noteworthy that there was a significant increase in turnaround time of the RAS test performed in their institution between 2015 and 2017, for a reason that would be interesting to know.

In accordance with our data, results of Barel et al. therefore confirm that despite many efforts and a well-organised nationwide network of molecular genetics platforms, the delay to obtain 
RAS mutational status in France remains long and has to be reduced to better match with clinical practice and with the therapeutic management of metastatic colorectal cancer patients. In order to reduce the delay of RAS test procedure without altering the quality of mutation detection, Barel et al. propose in their letter an alternative diagnostic strategy based on a first line molecular analysis with the fully automated real-time PCR Idylla ${ }^{\mathrm{TM}}$ system, which would be secondarily supplemented by a massively parallel sequencing only in non-mutated cases. Indeed, Idylla ${ }^{\mathrm{TM}}$ was shown to be faster than other existing molecular tests for BRAF and EGFR mutations detection in metastatic melanoma and non-small cell lung cancer [5-7]. It also has the advantage of allowing a mutational analysis directly on FFPE tumour tissue with a good or increased sensitivity compared to other standard molecular tests in different types of cancers including colotectal cancer [5-8]. Finally, Idylla ${ }^{\mathrm{TM}}$ system is an easy-to use test requiring less than five minutes of hands on time.

Therefore, we agree with the authors that Idylla ${ }^{\mathrm{TM}}$ method may be a way to reduce in part the turnaround time of RAS test. However, it is important to underline the higher costs generated by this full-automated system in centres with high volume of activity. Furthermore, Idylla ${ }^{\mathrm{TM}}$ is not able to reduce the time between request of the RAS test by physician and the receipt of tumour tissue by the molecular genetics platform that may be long (mean duration of 9.7 days in 2011 and 7.7 days in 2014 in our French experience) [1,9] as already mentioned.

To conclude, Idylla ${ }^{\mathrm{TM}}$ may be currently an interesting alternative to reduce the turnaround time of RAS test but we think that the search and validation of other methods (like liquid biopsy) that could bypass the time-consuming and limiting steps of unarchiving, selecting and dispatching samples to the molecular genetics platform is of greater interest to reach this goal.

\section{Authors' disclosures of potential conflicts of interest:}

AL: Merck, Shire, Ipsen (board member), Merck, Amgen, Roche, Lilly, Novartis (lecturer). JLM: Merck, Amgen (board member and lecturer), Sanofi (lecturer)

JCS: Merck, Amgen, MSD, BMS, Roche, Astra Zeneca, Pfizer, Boehringer Ingelheim (board member)

PA: Roche, Merck (board member) Sanofi, Amgen, Lilly (lecturer)

PLP: Merck, Boehringer-Ingelheim, Pfizer, Astra Zeneca, Biocartis (board member), Lilly, Sanofi, Roche, Astra-Zeneca (lecturer)

MD: Roche, Merck Serono, Amgen, Lilly, Sanofi, Novartis, Servier, Ipsen (board member and lecturer), Sanofi (grant) 


\section{References}

1. Lièvre A, Merlin JL, Sabourin JC et al. RAS mutation testing in patients with metastatic colorectal cancer in French clinical practice: a status report in 2014. Dig Liver Dis. 2018 May;50(5):507-512.

2. van Krieken JH, Siebers AG, Normanno N. European consensus conference for external quality assessment in molecular pathology. Ann Oncol 2013;24(8):1958-63.

3. INCa, editor. Bonnes pratiques pour la recherché à visée théranostique de mutations somatiques dans les tumeurs solides. Collection Outils pour la pratique des autres professionnels de santé / Anatomopathologie. Boulogne-Billancourt; 2010 [In French]. Available at: www.ecancer.fr/content/download/63175/568709/file/OUTTHERANOS10.pdf 4. INCa, editor. Synthèse de l'activité des plateformes hospitalières de génétique moléculaire des cancers en 2012, en vue d'optimiser leur evolution. Collection Bilans d'activité et d'évaluation. Boulogne-Billancourt; 2014 [In French]. Available at http://www.ecancer. $\mathrm{fr} /$ content/download/63494/571261/file/Synthese-activiteplateformes-hospitalieresgenetiquemoleculaire-en-2012-2014.pdf

5. Melchior L, Grauslund M, Bellosillo B, at al. Multi-center evaluation of the novel fullyautomated PCR-based Idylla ${ }^{\mathrm{TM}}$ BRAF Mutation Test on formalin-fixed paraffin-embedded tissue of malignant melanoma. Exp Mol Pathol. 2015 Dec;99(3):485-91

6. Harlé A, Salleron J, Franczak C, et al. Detection of BRAF Mutations Using a Fully Automated Platform and Comparison with High Resolution Melting, Real-Time Allele Specific Amplification, Immunohistochemistry and Next Generation Sequencing Assays, for Patients with Metastatic Melanoma. PLoS One. 2016 Apr 25;11(4):e0153576.

7. Ilie M, Butori C, Lassalle S, et al. Optimization of EGFR mutation detection by the fullyautomated qPCR-based Idylla system on tumor tissue from patients with non-small cell lung cancer.Oncotarget. 2017 Oct 4;8(61):103055-103062.

8. Johnston L, Power M, Sloan P, et al. Clinical performance evaluation of the Idylla NRASBRAF mutation test on retrospectively collected formalin-fixed paraffin-embedded colorectal cancer tissue. J Clin Pathol. 2018 Apr;71(4):336-343.

9. Lièvre A, Artru P, Guiu M, et al. The KRAS mutation detection within the initial management of patients with metastatic colorectal cancer: a status report in France in 2011.Eur J Cancer. 2013 Jun;49(9):2126-33. 